\title{
Climate Variability and Food Security in Africa: The Case of Small Pelagic Fish in West Africa
}

\section{Pierre Failler*}

Centre for the Economics and Management of Aquatic Resources (CEMARE), University of Portsmouth, Portsmouth, PO1 3LJ, United Kingdom

\begin{abstract}
The paper presents an analysis of the changes in fishing practices in West Africa both by national and foreign vessels and in trade patterns, as well as on the way in which these affect the economic and nutritional patterns of the Western and Central African countries, especially when climate variability is taken into account. Projections for the next decade indicate an increasing gap between estimated demand and supply under all scenarios elaborated. The more optimistic scenario shows that when environmental conditions are favourable, future fish supply cannot fulfil a growing population demand if per capita consumption remains at 2012 level. When environmental conditions are unfavourable, the supply-demand gap could rise to 1.8 million tonnes. However, even the best environmental conditions will not be able to satisfy the demand if the fish consumption per capita increases and the gap will progressively grow with time reaching 2.9 million tonnes in 2025 . The pessimistic scenario presents a worrying picture of the future supply of West Africa where the gap between demand and supply may reach 3.3 million tonnes in 2025 . In both scenarios, market mechanisms will adjust demand and supply by increasing the price of fish reducing therefore the accessibility for poor people and inhabitants of rural and areas far from the main fish markets. The foreseen deficiencies of fish supply will lead to nutritional loss, as some nutritional elements present in fish are not adequately represented in the foreseen substitutes (e.g. chicken). Therefore, climate variability increases the food security risks both in terms of quantity and quality.
\end{abstract}

Keywords: Nutrition, Fisheries, Pelagic fishes

\section{Introduction}

West African countries face major challenges related to nutrition [1]. Of a combined population of 226 million people ${ }^{1}$, nearly thirtyfive percent of children less than five years of age are stunted, a sign of a chronically poor diet while about 5 to $15 \%$ of young children die young, a sign of acute hunger. Deficiencies in vitamins and iron are widespread in West Africa and contribute to illnesses and high rates of child mortality. Iodine deficiency is a public health concern as well [1]. Knowing that fish can contribute up to $80 \%$ of animal protein supply in some parts of West African countries (FAO food balance sheets), the "New Partnership for Africa's Development (NEPAD) Fish For All summit in 2005, insisted on the importance of fish and marine products in of policies relating to food security [2], a recommendation that was already stated for all developing countries ten years ago during the International Conference on the Sustainable Contribution of Fisheries to Food Security with its subsequent Kyoto Declaration [3]. Despite these major events and a series of publications on fish and food security issues $^{2}[2,4]$, food security is still only today a prerogative of agricultural policy $^{3}$.

Taking into account climatic changes and climate variability, the implication on food production and availability in African fishing nations are similar to those relating more generally to food security in

${ }^{1}$ The area of West Africa, as defined in this paper, relates to the 15 countries of the Economic Community of West Africa States (ECOWAS): Benin, Burkina Faso Ivory Coast, Guinea Bissau, Mali, Senegal and Togo, as well as the 8 countries of the WAEMU (West Africa Economic and Monetary Union) as well as Cape Verde Gambia, Ghana, Guinea, Liberia, Nigeria and Sierra Leone, and Mauritania which left the ECOWAS on the $1^{\text {st }}$ January 2001. The main area for fishing activities is in the waters belonging to Morocco, Mauritania, Senegal, Gambia and Guinea Bissau while the main area of consumption covers the 16 countries mentioned above, as well as Morocco and Cameroon.

${ }^{2}$ Or fish and poverty [7], Aquaculture and food security [8], Trade and food security [9-13], future projections for fish consumption [14].

${ }^{3}$ For instance, the 2008 OECD and West Africa Club publication on West African Perspectives: Resources for Development or the FAO [15] publication on food insecurity in the world, don't mention fish as part of the food security issue. the whole of West Africa: only agriculture is considered. For instance, the workshop on Climate Change in Africa: Linking Science and Policy for Adaptation organized by the Tyndall Centre and IIED [5] focuses on land-based activities and ignores fish, seas, oceans and coastal zones. The World Fish Center (WFC), stressed nevertheless, since 2002, the importance of climatic changes and associated effects on coastal and marine areas for policy decisions. The two 2005 workshops of the Global Ocean Ecosystem Dynamic (Globec) on "the economics of small pelagics and climate change" and of the Department for International Development on the "Impacts of climate changes on fisheries" stressed the importance of relationships between climate, ecosystem production, capture production, food security and poverty. More recently, the new Canary Current Large Marine Ecosystem Project [6] under the Global Environment Facility program (GEF) highlighted the necessity of having a complete understanding of the consequences of up-welling changes on fish production, fisher communities' well-being and fish market supply [6].

This paper is an attempt to establish a link between climate variability, the production system, fish trade, consumption and food security in Africa. It focuses on small pelagic fishes because they are (i) highly influenced by climatic changes that affect the quality of the upwelling; and (ii) the major source of fish consumption of West African populations [16]. Thus, when the coastal upwelling is significant, pelagic fishes are generally more abundant and therefore markets for small pelagic fishes are satisfied [17]. During years of weak upwelling,

*Corresponding author: Pierre Failler, Centre for the Economics and Management of Aquatic Resources (CEMARE), University of Portsmouth, Portsmouth, PO1 3LJ, United Kingdom, E-mail: Pierre.failler@port.ac.uk

Received August 06, 2014; Accepted October 13, 2014; Published October 20 2014

Citation: Failler P (2014) Climate Variability and Food Security in Africa: The Case of Small Pelagic Fish in West Africa. J Fisheries Livest Prod 2: 122. doi: 10.4172/2332-2608.1000122

Copyright: (c) 2014 Failler P. This is an open-access article distributed under the terms of the Creative Commons Attribution License, which permits unrestricted use, distribution, and reproduction in any medium, provided the original author and source are credited. 
sardinella and other small pelagic species are less abundant and the risk of malnutrition increases for populations who rely heavily on fish for diet. Furthermore, the production system, or more precisely the fleet composition, has a significant impact on fish market supply and food security because nearly all foreign vessels operating in West African waters catch fishes for the international market. Fish consumption changes relate mainly to: (i) changes in fish supply (and related prices) and (ii) price link and substitution between fish and poultry products, and, (iii), to a lesser extent, changes due to revenues or time spent cooking [18]. Finally, from a trade perspective, small pelagics are affected by a double trend. On the one hand, stocks of demersal species (e.g. white fishes, shrimps, and cephalopods) are overexploited and exported by African countries to Europe as high commercial value goods, and a diminishing range of fishes remain available for local consumption: mainly small pelagics. On the other hand the new trade route of small pelagics to Asian countries absorbs growing quantities of small pelagics the availability of which on the African market will sharply decline.

The objective of the paper is to present major present and future issues on food security that are conditioned by current and future changes of the upwelling quality, the structure of the production system and trade and consumption patterns. It consists of 4 sections. Section 1 presents the state of small pelagic resources in West Africa and their close relationship with the upwelling. Section 2 gives an overview of the trade patterns of small pelagic fisheries from production to consumption. Section 3 shows the current consumption shifts and their nutritional consequences. Section 4 presents future trends based on four realistic scenarios that would require policy interventions while the conclusion summarises the main issues addressed in the paper.

\section{Small pelagic fishery in West Africa and climate variability}

Small pelagic fisheries: Figure 1 shows the geographical location of the West African small pelagic fisheries. Within the FAO division 34, the main areas that we refer to in this paper are the coastal sub-divisions 1.11 down to 3.13, and the oceanic sub-divisions 2 and 3.2. This geographical area includes the following coastal countries and entities (from North to South): Morocco, Western Sahara, Mauritania, Senegal, Gambia, Guinea Bissau, Guinea Conakry and, in front of Senegal, the archipelago of Cape Verde Islands.

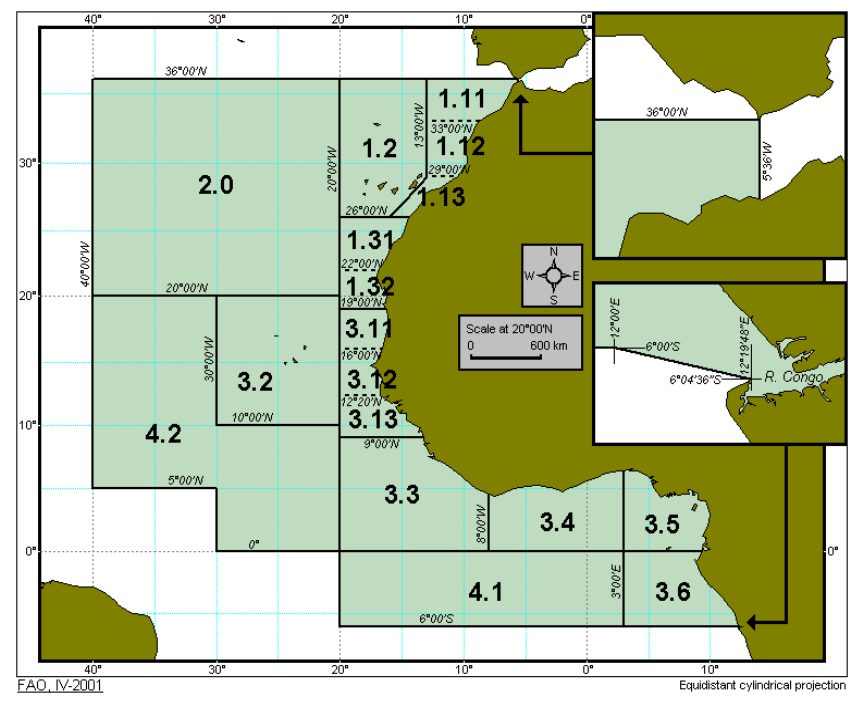

Figure 1: FAO division 34 and sub-divisions in West Africa and the CECAF area of competence (http://www.fao.org/fishery/rfb/cecaf/en).

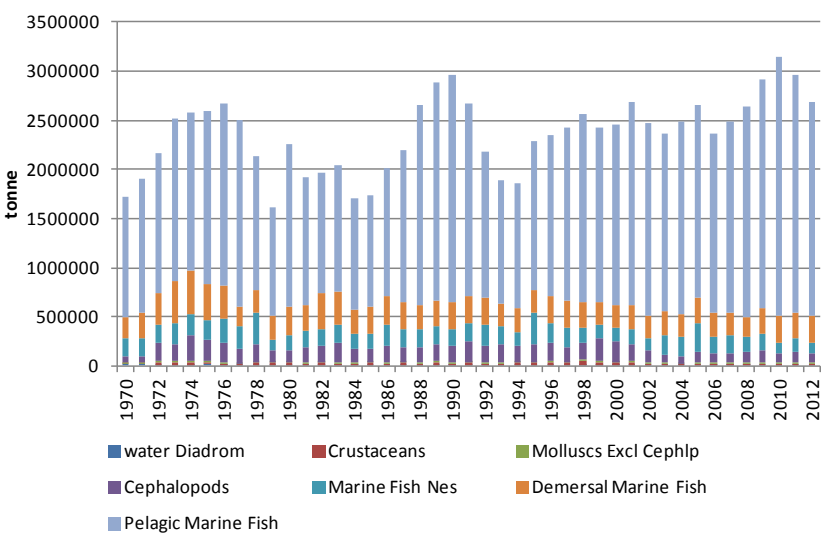

Figure 2: Landings per FAO group of species for divisions 1.11-3.13. 2. 3.2 and 4.2 (excluding tunas) [11].

Small pelagic fishes constitute the bulk (in tonnage) of all fish landings and are the most important marine resources in the waters of the coastal countries within the study area. These resources comprise the following families: Clupeidae, Carangidae, Engraulidae and Scombridae ${ }^{4}$. Due to their migratory nature, these resources are usually shared by many countries. On average, small pelagics landings reach 1.7 million tonnes [19] corresponding to 70 percent of the total reported catches (Figure 2). Among the most exploited pelagic stocks, sardines (European pilchards), sardinellas and mackerels are the three main species

For the purpose of this work, only sardinellas will be studied, as they are the main small pelagic species consumed by West African populations. Mackerel species, which yielded 250.000 tonnes in 2012, are targeted by vessels from Eastern Europe, which have been operating in the zone for four decades and, more recently, by European Union vessels. Frozen, these species supply some major African markets, for example, Nigeria.

The two species of sardinella are generally caught together. The round sardinella is usually the main target of the different fleets due to its higher commercial value and abundance in this sub-region ${ }^{5}$. Figure 3 presents the evolution of the total catches of sardinella in the whole zone between 1970 and 2012. From the figure below, it can be seen that the trends of the two species are fairly similar even if annual catches of flat or Madeiran sardinella are steadier around 100,000 t until 2009 from which date it doubles. In 2010, total landings of these species have found again their 1998 peak level after having cut by half to 350000 tonnes in 2006 (FAO, 2014b) [19].

${ }^{4}$ The Clupeidae consists mainly of the sardinellas (Sardinella aurita and $S$. maderensis) and the sardine (Sardina pilchardus). S. aurita (round sardinella) is concentrated in areas of cold water whereas $S$. maderensis (flat sardinella) prefers areas of lower salinity, often close to the river mouths. Two of the most important carangidae species are Trachurus trachurus (horse mackerel) and T. trecae (cunene horse mackerel) that live mainly between $25^{\circ} \mathrm{S}$ and $19^{\circ} \mathrm{N}$. Trachurus form very dense schools that can be fished down to 200 meter depths using a midwater trawl with a large vertical opening. The false scad (Caranx rhonchus) is distributed from Guinea Conakry to Dakhla (South of Western Sahara), a northern boundary where important catches are made between April and July. The Engraulidae is represented mainly by the anchovy (Engraulis encrasicholus). The scombridae is represented by chub mackerel (Scomber japonicus) found along the entire West African coast [19].

${ }^{5}$ The geographical entity called "sub-region" includes Mauritania, Senegal, Cape Verde, The Gambia, Guinea Bissau and Guinea Conakry. 


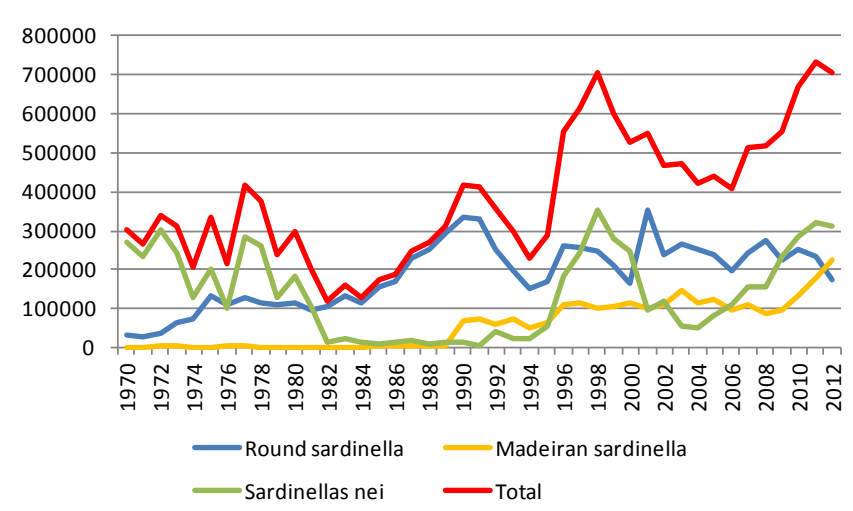

Figure 3: Catches of sardinella in Northwest Africa for divisions 1.11-3.13. 2. 3.2 and $4.2[19]$.

In Senegal, the largest landings are by the artisanal fishery ${ }^{6}$, which is constantly developing. Fishing is carried out in motorised canoes with diverse fishing gears such as purse seines, gillnets and beach seines. In Gambia, small pelagic fish, including sardinellas have not been targeted by the artisanal and industrial fleets since 1991. Consequently, landings are very low but the stock is largely the same that is exploited off Senegal. Sardinellas in Mauritania are caught mostly by pelagic vessels from the European Union, and in particular from the Netherlands, Latvia, Lithuania and Poland. Nine vessels operated in 2013 (compared to sixteen in the early 2000). In the area between Dakhla (South Western Sahara) and Cape Blanc (North of Mauritania), the fishery grew in importance at the beginning of the nineties. Fishing is mainly carried out by pelagic trawlers chartered by Moroccan fishers and operating under the fishing agreement between Morocco, the Russian Federation and Ukraine.

Management measures in place in Morocco, Mauritania, Senegal and the Gambia are based mainly on zoning, minimum landing size with respect to certain species, mesh-size regulations, protection of certain species, licensing systems and closed seasons [6]. The legislations in force prohibit some types of fishing. For example, it is forbidden to fish for marine mammals, and to use explosive and/or poisonous substances and electric discharges. The obligation to carry observers onboard vessels and to declare catches is a general measure in all countries. Fisheries surveillance projects working in close collaboration with a regional project based in the Gambia are in place.

Climate variability and small pelagic abundance: The West African coast from Morocco to Guinea Conakry includes the Canary Current large marine ecosystem [6] and the northern part of the Guinea Current LME (GCLME). The CCLME is characterized by its temperate climate. It shows major upwellings and other forms of seasonal nutrient enrichments. Hydrographical and climatic conditions play a major role in driving its dynamics leading to seasonal and longer-term variations. It is classified as a Class I highly productive ecosystem with a productivity of more than $300 \mathrm{gC} / \mathrm{m}^{2}$-yr according to global primary productivity estimates from SeaWiFS [20].

Several observations in FAO Area 34 show causal links between upwelling and abundance of small pelagic species $[21,22]$. For instance, landings of pilchards in northern Morocco (Zone A) are linked ${ }^{6}$ The industrial fleet was made up of small purse seiners or small tonnage sardine boats known as "sardiniers Dakarois. Their number has been in continual decline for a number of years. In 2013, only two were still fishing. During the eighties and nineties, large tonnage purse seiners and trawlers from USSR fished in the Senegalese exclusive economic zone (EEZ). The purse seiners disappeared in 1994 and the pelagic trawlers in June 1999 with the stop of the fishing agreement. negatively to rainfall and positively upwelling strength. Off Ghana and Côte d'ivoire, catches of $S$. aurita are more important during the cold season and are correlated to the intensity of the upwelling. In Senegal and Côte d'ivoire, catch per unit of effort (cpue) of sardinellas is linked to an upwelling index. Binet [23] mentions that, generally speaking, $S$. pilchardus (pilchards) is the small pelagic species that responds most positively to the upwelling strength in the FAO subdivisions 1.11 and 1.12. S. aurita and S. maderensis respond differently to the upwelling and the environmental conditions that prevail at a given location. For instance, $S$. aurita will react positively to the upwelling in Senegal but far less in Mauritania where this species reaches the northern limit of its distribution. According to Binet [23], we can even consider the inverse reaction: the cpue for this species is the highest during the hot season offshore of Mauritania. The hypothesis behind these observations is that an intensification of the upwelling increases the quantity of plankton, which in turn, improves the feeding and survival condition of larvae, thus their recruitment. For instance, the year 1999, which can be considered as one of the rainiest years in the Soudano-Sahelian region, saw the lowest temperatures in Senegal since the beginning of the 90s (Figure 4) and the highest biomass of sardinellas estimated at 3.6 million tons (compared to a biomass that fluctuates between 1.3 and 3 million tons).

As Binet [21], Roy and Cury [24] and more recently Zeeberg et al. [25] pointed out, the wind is the driving factor of the coastal upwelling along the West African coast. During the cold season, winds cause a reduction of sea surface temperature (SST). Upwelling is permanent between $19^{\circ} \mathrm{N}$ and $28^{\circ} \mathrm{N}$ (from the Banc d'Arguin to the Canary Islands) and occurs only during winter south of $19^{\circ} \mathrm{N}$. So, wind occurrence declines from the north to the south of the region. As a result, average SST rises from Nouakchott (Mauritania) to the Casamance region (south of Senegal). Given that there is only one stock of S. aurita and one of S. maderensis [12], the existence of two large nurseries and the wide distribution of the stocks from Casamance to the north of Cape Blanc (Figure 5), it is possible to envisage the correlation between SST and sardinella biomass.

Therefore, one can use the SST as index of upwelling. Following results from Failler and Sambe [16], for the stock surveyed in Senegal, there is strong adverse relationship between SST and the abundance of both sardinellas, as $S$. aurita and $S$. maderensis present the same correlation patterns. In Casamance, one of the two nursery areas for sardinellas, the correlation is negatively high $(-0.86)$. As we move to the north of Senegal, this correlation coefficient decreases, suggesting that temperature affect less and less the abundance of sardinellas in

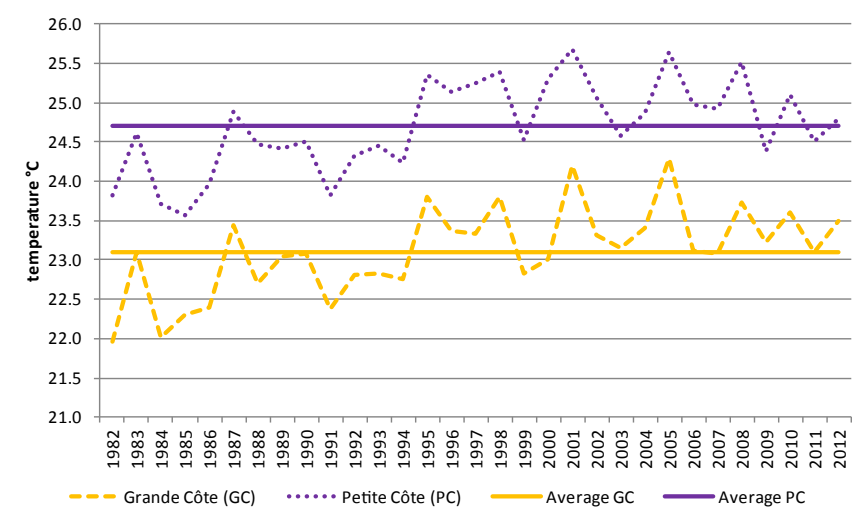

Figure 4: Average sea level temperature from satellite along the Senegalese coast. 

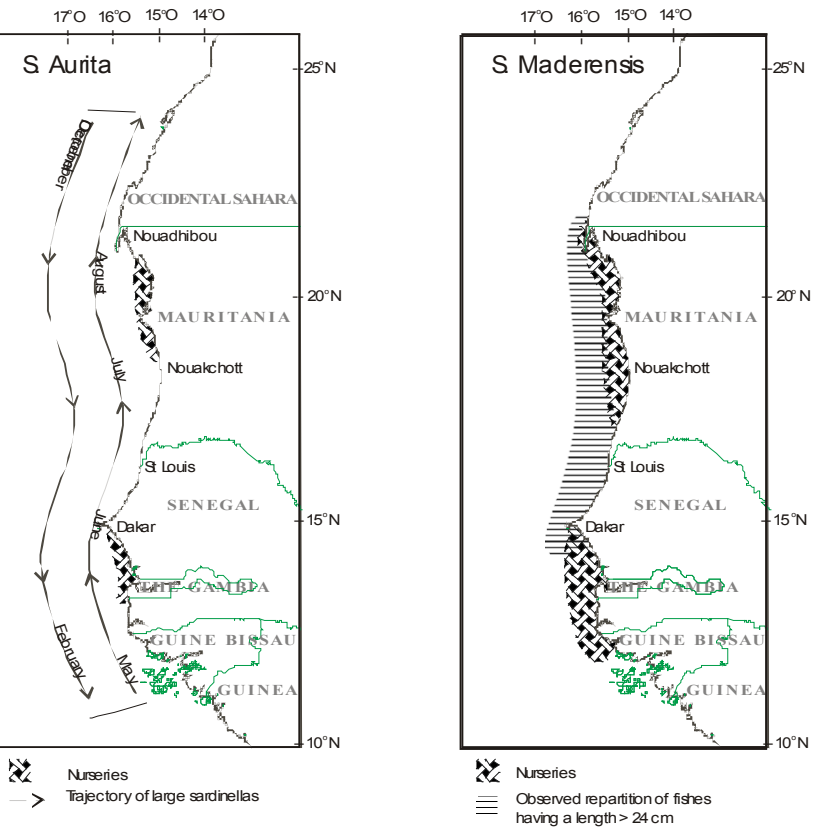

Figure 5: Nurseries. migratory patterns and spatial distribution of $S$. aurita and $S$. maderensis exploited by the Senegalese fishery (adapted from P. Fréon. 1984)[22]

Senegal. In Mauritania, the abundance of S. aurita and S. maderensis show a different pattern than in Senegal. The increase of SST at Nouakchott has a positive effect on sardinellas species $(0,89)$ since we start to reach the northern limit (Cap Blanc) of the geographical distribution of sardinellas. Thus, over the last few years, a downward trend of the intensity of the upwelling and a rising water temperature was recorded in North of Mauritania and South of Morocco, resulting in the displacement of the thermal front further north, causing a massive displacement of sardinellas north of Cape Blanc as a result [12]. European fishing vessels felt the early migration of the sardinella to Moroccan waters in the autumn of 2001-2002 related to the high water temperatures that season. Zeeberg [26] and more recently Braham et al. [27] agreed that there is a connection between the fall in catch and the changes in water temperature that cause the sardinella to remain in Moroccan waters for a longer period of time. As Roy and Reason [28] pointed out, the variability of the climate and temperature in the CCLME is related to the El Nino/Southern Oscillation (ENSO), adding a new dimension to the understanding of the causality between climate variability and fisheries. Nevertheless, it is possible to outline some general trends. For Roy and Cury [24], decadal climatic changes occur in the CCLME that affect the fish population and particularly the distribution and abundance of small pelagics with some synchronicity with the upwelling and the ENSO.

\section{Trade patterns and recent changes}

Many trade patterns coexist for the sardinella caught in West Africa. Among the various trade systems and routes that are presented in Figure 6, we can define three major routes: one regional (small scale fishery and West African consumption) and two international ones (Distant water fleets and traditional markets in Europe and Africa; European fleet and Asian market).

\section{Artisanal production for West African markets}

The first route involves sardinellas caught by African fishermen from canoes or small coastal boats and landed fresh. These are consumed fresh by the local population or processed, using drying and smoking techniques, and consumed by both national and West Africa populations. This trade system supplies roughly 100.000 tonnes per year of fresh fish and 30.000 tonnes of cured fish to markets of Mauritania, Senegal and the Gambia and 120.000 tonnes of dried/smoked products to neighbouring countries [17]. The industrial fleet, mainly operating under freight contracts in Mauritania ${ }^{7}$ provides 20000 tonnes both for human consumption and fish meal reduction.

Although they are generally not recorded, the processed products of the artisanal sector constitute a significant part of the intra-regional trade of sardinellas and other small pelagic species. These exchanges increased considerably during last few years [17], but the official data still do not suitably reveal them because these activities are not recorded (while import and export of frozen products are recorder). The latter are well recorded since they use maritime routes and harbour facilities where customs operate effectively. The fish processed by artisanal processors fish circulates especially over land, in trucks, vans, passenger vehicles, taxis, even motorcycles and cross borders sometimes without customs declarations. One can, however, identify a certain number of trade-circuits:

- From Senegal: towards Cameroon, Congo, Côte d'Ivoire, Gabon, Ghana, Guinea, Nigeria, Togo, Benin, Zaire and Mali for dried and smoked sardinellas

- From Mauritania: towards Ghana, Nigeria and recently Mali for dried and smoked sardinellas and other small pelagics.

- Two other routes in the Gulf of Guinea are important, as they are part of the distribution system of sardinellas caught and processed in Mauritania and Senegal:

- From Ghana: towards Togo, Benin and Nigeria for smoked sardinella.

- From Côte d'Ivoire: towards Burkina Faso for smoked sardinella.

\section{European trade system from Las Palmas}

The second trade system involves the Ex-USSR and European fleets. The political disaggregation of the USSR resulted in a significant reduction of the number of operational vessels in West Africa. The remaining vessels continue to navigate today under freight contracts with Mauritanian companies. The Dutch fleet started to operate in

${ }_{7}^{7}$ The Senegalese industrial fleet has practically disappeared in the $90 \mathrm{~s}$.

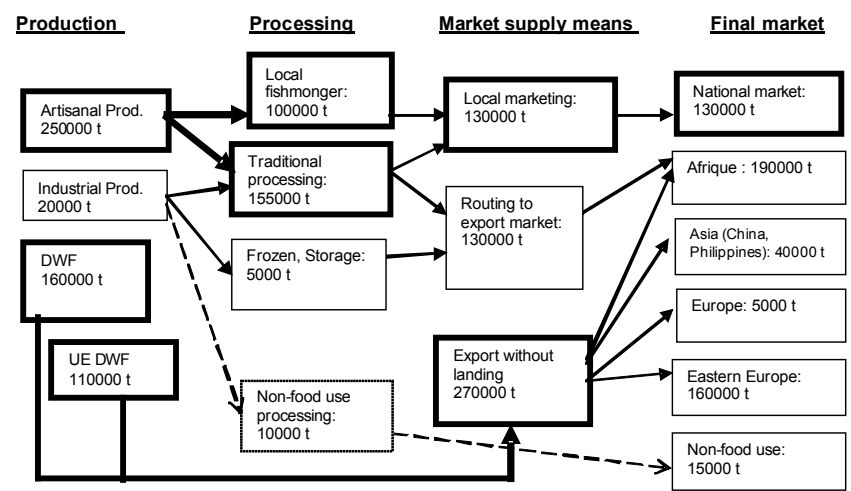

Figure 6: Average yearly (2003-2012) sardinella production. processing and distribution (note: DWF='Distant water fleets; all figures are in live weight equivalent) 
Mauritania in 1992 under private licences. Since the new protocol of the EU/Mauritania fishing agreement in 1996, this fleet functions under a public statute. Some EU vessels from Ex-URSS States have recently joined the Dutch vessels within the framework of the fishing partnership agreement between the EU and Mauritania.

The departure of the ex-USSR fleet and the arrival of the European pelagic fleet led to some major changes in trade. The ex-USSR fleet fished mainly to supply the Soviet countries and, occasionally, the West African market, as a way to obtain the hard currency, necessary for the operation of the vessels. The European fleet started fishing with the objective of supplying the West African market, especially the Nigerian market using the already established Dutch trade connection. Thus, the arrival of the EU fleet has to be perceived as a complement to the existing Dutch merchant system that is used to sell small pelagics from the North Sea and other European waters such as horse mackerel, jack mackerel and chub mackerel to Nigeria and neighbouring countries. Under the umbrella of "The Group", which is the marketing and export organisation of the Pelagic Freezer-trawler Association (PFA) ${ }^{8}$ that owns European vessels operating in West Africa, exports occur from Las Palmas. In this important port, new harbour facilities have been built since the beginning of 2000 to facilitate the landing of small pelagic fish landed by EU vessels, their frozen storage and the uploading of containers on cargo vessels.

From 1996 to the beginning of the 2000 decade, the trade pattern of the European company in West Africa was quite simple as the purpose was to supply highly demanding countries such as Nigeria. This objective was reasonably achieved, as The Group was able to provide approximately 300 to 350000 tonnes of small pelagics to Nigeria, the bulk of which came from West African waters, the remainder from European waters. As shown in Figure 7, Nigerian imports have been positively affected by the presence of European vessels in Mauritania and Moroccan waters, as their levels rose significantly when the EU vessels started to operate at a large scale and on an annual basis, in 1996.

In the mid-2000 the decrease of the captures of sardinella off the coast of Mauritania led to the displacement of European vessels to the North Sea where they made significant catches of mackerel, notably in 2006 and 2007. A significant part of these catches has been exported to Nigeria at a very low price, doubling the imports from previous years. Since 2008, the import of mackerel is back to their previous levels.

The trade system was the following: frozen sardinellas landed in Las Palmas were stored and then shipped to major African markets, such as Nigeria, Ivory Coast, Ghana, Cameroon, Congo and the Democratic Republic of Congo. In these countries, frozen fish imports constitute the category most widely distributed, through a network of privately owned cold stores located in major cities. The fish is available frozen in city markets, and part of it is smoked for further distribution to village markets. The freshly frozen landings of the industrial fish trawlers also follow the same distribution network, but their availability, far beyond the coastal landing sites, is constrained by its limited quantity relative to the cheaper imports of pelagics from Las Palmas [29].

\section{New Asian trade route}

Since 1999, new markets for African sardinellas and other small pelagics have been developed in Asia, particularly in China and the Philippines. Figure 7 above presents the trend over the last decade of small pelagic imports of Nigeria, China and Philippines. The Chinese

8The Pelagic Freezer-trawler Association represents the interests of 8 European pelagic trawler companies on an international level. At present, the association has members in England, France, Germany and The Netherlands, all operating freezer-trawlers that catch and process pelagic fish for human consumption. market starts in 1999 both for supplying the national market and for processing the fish which is re-exported in cans to Africa or Europe. Market opportunities in Asia are driven by three main factors that are examined in more detail below:

- the ease of access of the Asian market compared to the African market;

- the high prospect that Asian market will offer in the near future and

- the customs by-pass that Asian processing can offer.

Easier access: With lower business risks and less administrative annoyances (hence easier circulation of goods), the Asian market appears to be more attractive than its African homologue. As pointed out by Failler et al., [12], administrative annoyances can be so high, that tradesmen give up trading. Average prices don't seem to explain the attractiveness of the Asian market. As shown in Figure 8 [30], since 1998, average import prices are higher in the Nigerian market than the Chinese market and all the time, greater than the Philippines market. Explanations are maybe in the volumes of trade.

Higher prospects: The Nigerian and other West African markets have a demand for low price fish for direct human consumption as the population cannot afford to buy high value commercial species. West African countries do not have great room for manoeuvring to negotiate prices, as the alternative sources are few or non-existent.

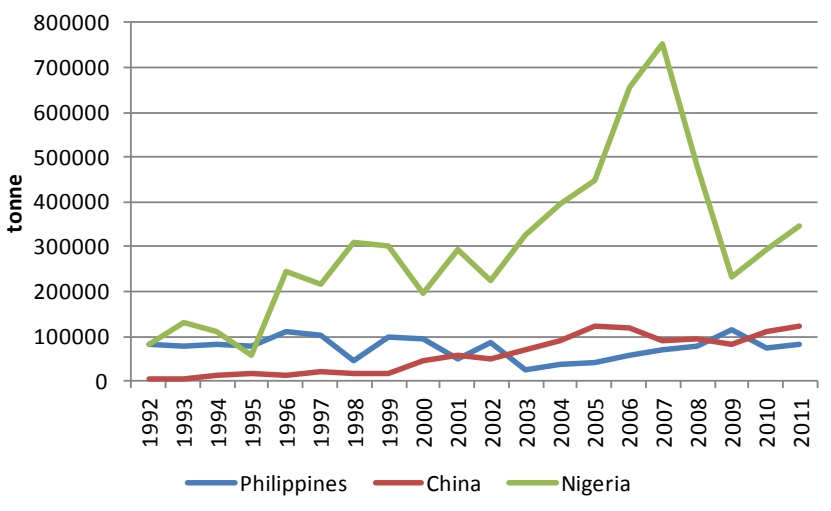

Figure 7: Imports of sardinellas by China. Nigeria and Philippines.

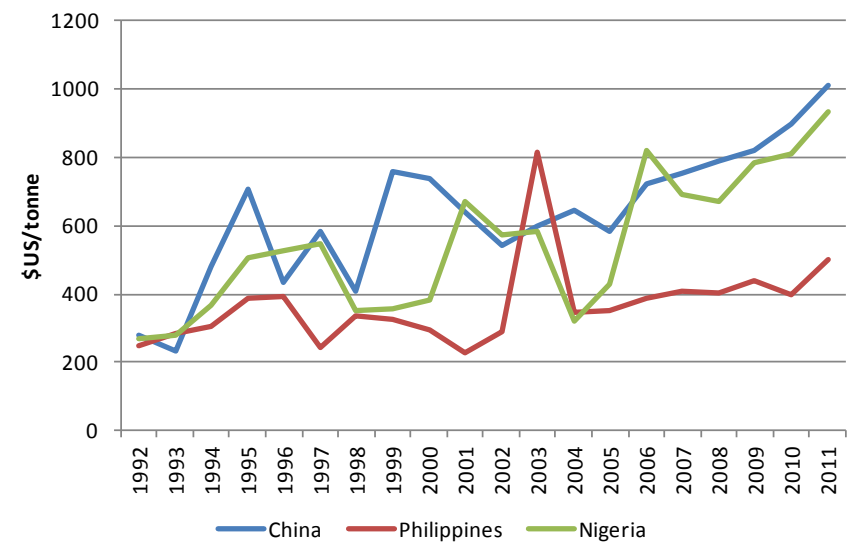

Figure 8: Average price of imports of frozen sardinellas by China. Nigeria and Philippines [30]

Source: FAO. 
The situation of having The Group as the only supplier reinforces the precariousness of importing nations in two ways. Firstly, The Group can dictate prices as it wants; the low negative correlation factor $(-0.26)$ obtained between price and quantity from 1996 to 2005 reflects the poor relationship between supply and demand; a situation that only a malfunctioning market can generate (for comparison, for China, the negative correlation coefficient is -0.50 , which indicates a certain negative response of price to supply quantities, which shows that market mechanisms are functioning; Failler, 2005) [16]. The second concern is the path dependency that The Group has created in Nigeria, Ghana, Cameroon and other fish importing nations in West Africa. By being the only provider, The Group generates a situation in which, for West African countries, it is easier and cheaper to deal with one supplier than make the effort to develop a multi-supplier system. How does it affect the food security of these countries? For instance, in Nigeria, The Group provides nearly half of the fish consumed by its 120 millions inhabitants (nearly 3 of the $6 \mathrm{~kg}$ consumed per caput per year) (http:// www.pelagicfish.eu/). Nevertheless, the raise of aquaculture production in recent years, from $25000 \mathrm{t}$ in 2008 to 250000 in 2013, will contribute to supply the national market and limit somehow the imports.

The recent and future increase of the purchasing power of households in Asia compared to the stagnant perspectives in West Africa is itself an explanation of the development of small pelagic exports to Asia. The increasing future demand for fish products in China [31] will guarantee an increasingly significant flow of marine products up to the point where households will prefer high value commercial species such as white fish, shrimp and cephalopods over small pelagics.

Customs' by-pass: The third important market factor to consider for the Asian market is the possibility to develop a system where custom duties in Europe for products coming from China are null. As Van den Brink [32], in the PFA news, pointed out, "Blue whiting enters China as an entire fish and leaves the country as fillets. By re-exporting after processing, the Chinese importer pays no import duties. In contrast to Eastern Europe, the EU countries levy a 15\% import duty on the filleted fish. But if the exporter of the whole blue whiting is the same as the importer, i.e. he remains the owner of the product and he commissions his product to be processed in China, the excise authorities can issue a licence for the return of the fillets to the EU at a zero rating. For this to happen everything has to be subjected to appropriate administration and, for instance, DNA tests must be able to demonstrate that the fillets really are from the same blue whiting that left the EU several months before. It is not a simple exercise, but in view of the levels of the current duty rates it represents a commercial challenge of the highest order".

This custom by-pass is possible because of the higher technological and sanitary levels of the processing plants in Asia compared with the West African plants that, often, do not comply with international quality standards and therefore are looking desperately for raw material. The development of the Asian trade system indicates that capture of small pelagics by DWF in West Africa will only continue to supply markets of West African countries as long as the price remains attractive and the administrative annoyances don't generate too many obstacles to trade.

\section{Fleet Structure, Market Supply and Consumption}

\section{National and European fleet strategies and their nutritional consequence}

Species targeted by the European fleets are those heavily exploited by national fleets and exported in high quantities to the European Union, and also Japan in the case of cephalopods (Table 1; Chavance et al., [33]). Analysis of the different national fleets and their national fish market supply shows a progressive decline in supply due to increasingly higher incomes obtained through sales to export markets. On small local markets, only those products with a low commercial value are available. However, in years where there is no measurable growth in catches and exports (there is a very strong correlation between catches and exports), there is a reduction in the net supply of fish to the local market. The scarcity of high value species, on one side, and the difficulty of maintaining the high level of imports, on the other side, has lead to a compression of national market supply [12,34].

All that would be of no consequence if fish did not represent a significant source of animal protein for the coastal populations of West Africa. Table 2 below presents the average fish consumption for Morocco, Mauritania and Senegal. Figures presented don't reflect the actual consumption of coastal population which is about $30 \mathrm{~kg} / \mathrm{inh} a \mathrm{~b} / \mathrm{y}$ for Morocco and Mauritania and about $50 \mathrm{~kg} / \mathrm{inh}$ ab/y for Senegal [35,36]. For instance, in Senegal, consumption the small pelagic species, primarily sardinellas, represents nearly $75 \%$ of the overall fish consumption. Sardinellas are mainly transformed into Kéthiakh (fish that is braised, salted and dried; $50 \%$ of the production). In the distant rural zones of the coast, the traditionally processed products are generally used as a substitute for the fresh products. In Mauritania, with a population of 3 million of inhabitants, of 13000 tonnes are unloaded on average per annum by artisanal fishing, approximately 3000 tonnes are transformed locally into dried or salt-dried fish, before being sent to the interior of the country or exported to the bordering countries (Mali, Senegal) by local or foreign wholesale fish merchants. 10000 tonnes are transported in the form of fresh fish under ice, often in vans, towards the hinterland, especially towards the Senegal river valley, where the populations are accustomed to consuming fish [17].

Small pelagic fishes replaces meat in coastal towns: price of fish is lower than that of meat: Since 1970, migrations towards the large coastal urban centres were accompanied by changes in consumption patterns in which fish gradually replaces meat. For instance, populations of the Sahara, which have been pushed to the coastal cities during the drought years, have changed their food practices as they urbanized by consuming fish. Two reasons explain the substitution of meat by fish over the last three decades. The first one is the abundance of small pelagics at moderate prices due to production surpluses achieved by the artisanal fleet. The second is linked to the high price of meat products in coastal areas, particularly red meat (coming from the cattle-rearing areas of the hinterland) and white meat (coming from intensive farming and imports) [16].

\begin{tabular}{|l|c|c|c|c|c|}
\hline \multicolumn{1}{|c|}{$\%$} & Small pelagics & Tunas & Demersal fish & Cephalopods & Shrimp \\
\hline Morocco & 50 & 90 & 70 & 95 & 90 \\
\hline Mauritania & 95 & 95 & 90 & 100 & 95 \\
\hline Senegal & 15 & 90 & 90 & 95 & 95 \\
\hline
\end{tabular}

Table 1: Percentage of the national fleet catches that are exported from Mauritania. Morocco and Senegal (average 1990-2005) [35]. Source: Failler.

\begin{tabular}{|l|c|c|c|}
\hline & Mauritania & Morocco & Senegal \\
\hline $\begin{array}{l}\text { Consumption per inhabitant (kg/inhab./ } \\
\text { year) }\end{array}$ & 13 & 8 & 31 \\
\hline Proteins (Grams per day) & 4 & 5 & 9 \\
\hline $\begin{array}{l}\text { Fish proteins /Total proteins of total } \\
\text { population }\end{array}$ & $5 \%$ & $3 \%$ & $13 \%$ \\
\hline $\begin{array}{l}\text { Fish proteins /Total proteins of coastal } \\
\text { population }\end{array}$ & $\mathbf{3 0 \%}$ & $\mathbf{2 5 \%}$ & $\mathbf{8 0 \%}$ \\
\hline
\end{tabular}

Table 2: Fish consumption in Mauritania. Morocco and Senegal (average 19902010) [36].

Source: FAO 
Fish as a luxury product: In the last decade, a price inversion has occurred in Senegal, Mauritania, Morocco and Gambia: the price of meat (especially white meat) has declined relatively to the price of demersal fish (from 0.5 to 2). Due to the high level of exports of demersal fish or products, the supply of the domestic market is limited. Examples from these countries show that demersal fish (formerly a basic food) now have the status of a luxury food product [37] while small pelagic fishes stay affordable for the whole society.

Opposite trend for middle class: If migration to coastal urban centres tends to increase fish consumption, diet patterns of the growing middle class in cities have evolved in an opposite direction over the last decade. Urban households have expressed an increasingly strong preference for ready-made products. This phenomenon may partially explain the increase in consumption of white meat (easier to prepare than fish) and thus contributes to the substitution between fish and meat. But its contribution to the explanation is modest, taking into consideration what occurred in Europe: a progressive increase in the consumption of fish during the last decade at the same time as an increase in the white meat consumption [35].

In a more general way, changes in the patterns of fish consumption may not always be visible in statistics given for average consumption per capita per annum. However, what is clear is that there is indeed a profound change in the pattern of fish consumption. Increasingly, there has been a marked decrease in the quantity of high value (and quality) fish species consumed, with species of low commercial value eaten instead. In addition, fish supply has been increasingly restricted to coastal areas and large urban centres.

Overall, there is a strong correlation between an increase in price for high value species on the international market and the growing scarcity of these species on national markets. Consequently, exported species are seldom available on local markets, and even when they are available, they are frequently sold at prices that are too high for local households. In this context, the absence or low level of landings (except for small pelagics, which are abundant in good upwelling conditions), and the volume of exports has a number of effects:

- A decrease in the availability of fish on the national markets and a rise in prices (a corollary due to the current scarcity of the resources), which in turn leads to a decrease in the purchasing power of West African households, the majority of which already live below the poverty line;

- Traditionally consumed species are being generally replaced by species that were either not consumed, or rarely so, a decade ago. In addition, as species of high commercial value are largely unavailable, there, in higher income households, an increase in consumption of species that were previously left for households on lower incomes. In the first case, a change of consumption patterns can be observed without a perceptible reduction in nutritional or energy values, as shown in Table 3 [38-41]. In the second case, however, the rising price of lower commercial value species is denying poorer households their traditional supply of fish. Altogether, this results in a reduction in the choice available to the population, increasing their vulnerability because of an increased dependence on a reduced selection of potential goods for consumption.

- The substitution of poultry for fish occurs because of lower prices for white meat than for fish (poultry that is to some extent imported from Europe in particular thanks to export subsidies).

- The opposition of West African public opinion to the fishing agreements because of the impression they have that they are being cheated of their fish. Even if the Mauritanian society is not currently expressing itself on the subject, the forthcoming negotiations regarding the agreements are likely to see voices rising on the issue.

\section{West African fish supply and food security in $\mathbf{2 0 2 5}$}

According to the United Nations report on the population to 2300

\begin{tabular}{|c|c|c|c|c|c|}
\hline Species & FAO Code & Species Group & Energy (Kcal) & Protein (g) & Lipid (g) \\
\hline Octopus nei & OCT & Cephalopods & 82 & 14.91 & 1.04 \\
\hline Lesser African threadfin & GAL & Demersal & 87 & 19.2 & 0.60 \\
\hline Flatfishes nei & FLX & Marine fish. demersal & 91 & 18.84 & 1.19 \\
\hline Cuttlefishes/bobtail/squids & CTL & Cephalopods & 92 & 15.58 & 1.38 \\
\hline Pargo breams nei & SBP & Demersal & 92 & 18.4 & 1.50 \\
\hline Congo dentex & DNC & Demersal & 92 & 18.8 & 1.30 \\
\hline Groupers nei & GPX & Demersal & 92 & 19.38 & 1.02 \\
\hline Goatfishes. red mullet nei & MUM & Demersal & 96 & 20.4 & 1 \\
\hline Skipjack tuna & SKJ & Pelagic/Tunas & 100 & 20.51 & 1.34 \\
\hline Snappers nei & SNA & Demersal & 100 & 20.51 & 1.34 \\
\hline Sardinellas nei & SIX & Pelagic & 101 & 21 & 1.9 \\
\hline Shrimp & $\mathrm{CNZ}$ & Crustaceans & 102 & 17.9 & 0.6 \\
\hline Common shrimp & $\mathrm{CSH}$ & Crustaceans & 120 & 23.08 & 1.96 \\
\hline Shark & $\mathrm{SKH}$ & Demersal & 130 & 20.98 & 4.51 \\
\hline Chiken & & & 139 & 19 & 12 \\
\hline Hakes nei & $\mathrm{HKX}$ & Demersal & 142 & 21.8 & 5.4 \\
\hline European pilchard(=Sardine) & PIL & Pelagic & 143 & 17.6 & 7.5 \\
\hline Jack and horse mackerels nei & JAX & Pelagic. small & 143 & 25 & 4 \\
\hline Plain bonito & BOP & Pelagic & 151 & 22.6 & 6 \\
\hline Yellowfin tuna & YFT & Pelagic/Tunas & 170 & 24 & 7.5 \\
\hline Atlantic mackerel & MAC & Marine fish. pelagic & 205 & 18.6 & 13.89 \\
\hline
\end{tabular}

Table 3: Nutritional values of some fish species and chicken 


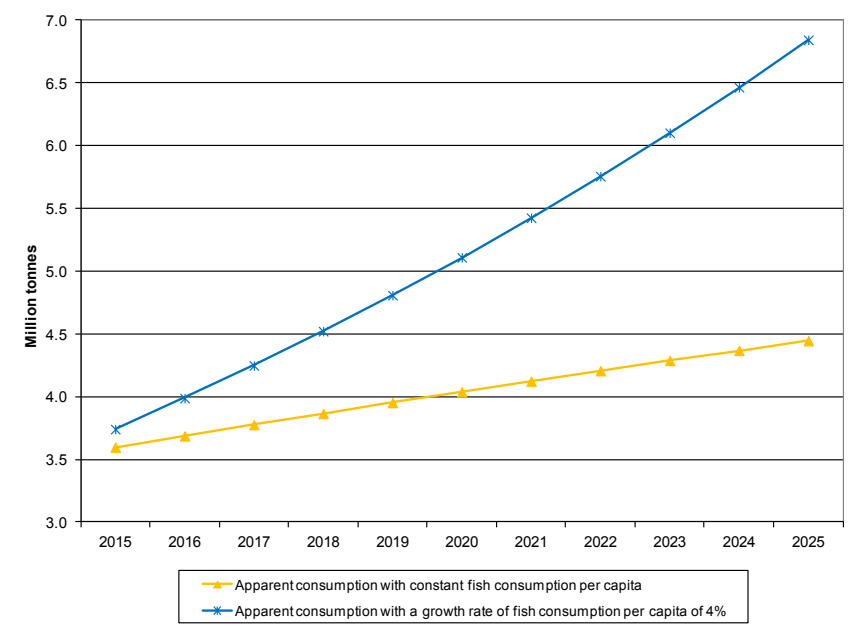

Figure 9: Apparent consumption of fish in West Africa 2015-2025 (with 2012 as starting point).

(United Nations, 2013), the African population from 2010 to 2025 will rise but with a decreasing rate. Currently the growth population rate is $2.5 \%$ per year. This rate will decrease annually by $4 \%$ until 2025 . Considering the current population of West Africa of 310 million [42], the figures for 2025 will be about 400 million people. If the annual consumption level of $10.8 \mathrm{~kg} /$ capita/year (equivalent to 3.3 million tonnes of net supply ${ }^{9}$ ) observed in 2012 is maintained, the total consumption will reach 4.4 million tonnes in 2025. It would reach 6.8 million tonnes with a growth annual rate of the per capita consumption of $4 \%{ }^{10}$ per year (18 kg/capita/y in 2025). a shows both trends of the net supply from 2015 to 2025 .

The supply gap between 2012 and 2025 is therefore approximately 0.8 million tonnes at constant consumption rate. It extends to 3.1 million tonnes if consumption rate improves. In both cases, it means that production from national fishermen or imports will have to increase. Taking into account the fact that most of the marine resources in West Africa are already fully exploited or over-exploited [43], it seems rather impossible to satisfy the various levels of future demands by increasing national catches. Furthermore, the climate variability, as we saw earlier, will continue to affect the abundance of small pelagics and therefore catches. The supply of fishing and importing countries will have, on annual basis, to deal with fluctuation of landings and imports respectively. In order to facilitate the presentation of future scenarios, the next section focuses on economics and social aspects of demand and supply of fish while the following section presents scenarios with climate variability.

Fish exports are such a precious means for coastal States to raise funds and hard currency, that it is doubtful that they will decrease in order to improve the supply to African markets. If this happens, it will be due to the decrease of catches, as already happening with certain high commercial value species in Senegal [44]. Consequently, the increasing need for fish is unlikely to be satisfied by the rerouting of global imports towards African national markets. The purchasing power gap between African and other developing or emerging countries' households will

${ }^{9}$ The apparent consumption figures are obtained by multiplying population figures by consumption per capita figures. The apparent consumption corresponds to the net supply needed to satisfy the demand. All figures are in live weight equivalent.

${ }^{10}$ Based on the average growth of the consumption rate of small pelagic fishes in countries of the SRFC over the period 2000-2009. continue to aggravate in the next decade, resulting in a reinforced attractiveness of the international market against the national one (unlikely to be compensated by an increased economic development and revenues of households). In other words, market competition will make it more and more difficult to supply African markets. Even for small pelagics, the Asian market will attract growing quantities of sardinellas, reducing the availability both for fishing nations (e.g. Mauritania and Senegal) and less competitive importing nations (e.g. Nigeria and Côte d'Ivoire). In other words, the next important change that we can already predict in the fishery sector in West Africa is the export of larger quantities of small pelagics by the small-scale fishing sector out of Africa (on the top of the current industrial sector). It is a logical extrapolation of what already happens with high commercial value species such as white demersal fish, cephalopod, shrimp and tuna.

Within African countries, as the urbanisation of the population will continue over the next decade, trade flow will be much more concentrated on cities, leaving the countryside and remote areas without fish. The improvement of the cold chain between harbours and cities will also lead to some changes in the way products are processed. The smoking and drying of fish will progressively disappear in favour of fresh and refrigerated conditioning. This shift will be promoted by environmental organisations that consider the utilisation of wood for fish smoking as one of the main cause of the deforestation in West Africa. The processing and conditioning change will be exacerbated by the raising demand of fresh fish and ready-to-cook fish products from the middle class population who live in the cities. On the whole, urbanisation and improvement of purchasing power of the middle class will aggravate the current decrease in the supply to areas distant from landing sites and cities. The polarisation of fish flow within cities will generate tension between urban areas and the countryside and lead to major concerns in terms of food security.

A solution to reduce the gap between what will be available and what will be needed is to import fish or fish substitutes, for example, chicken. The increasing level of purchasing power of households in the cities will make fish imports possible, but in a very limited way. The main way of filling the gap will be to import chicken from Europe and more and more from Asia (Thailand, for instance) where production costs are lower. We can envisage a situation where Africa exports more fish and imports more chicken. The recent development of the Asian market for sardinellas can be extended. African countries will benefit from this trade development, as it will generate imports and exports revenues for the national treasuries. On one hand, consumers also seem to profit from this change since the price of chicken is less expensive than the majority of fish species. On other hand, they will suffer from it because the fish contains essential omega 3 fatty acids not present in chicken (which are rich in omega 6 fatty acids from corn and soya feeds). In other words, the switch from fish to chicken seems beneficial at first glance, but is not the case if one takes into account the aspects related to human nutrition ${ }^{11}$

Scenarios without climate variability: From what has been presented above, we can elaborate on 2 scenarios for the future considering the demand trend, with and without the increase of fish consumption per capita (Figures 10-13). The first scenario (Figure 10) consists of the maintenance of the fish availability at its 2012 level for the period 2015-2025. In this case, as we mentioned above, the missing supply will be between 1.1 and 3.5 million t. The second scenario (Figure 11) is to increase imports to satisfy the growing demand of ${ }^{11}$ There is evidence that a regular intake of fish, principally, but not only, as a source of long chain omega 3 fatty acids protects from a number of health problems and diseases including cardiovascular disease, certain cancers, and mood disturbance [45]. 


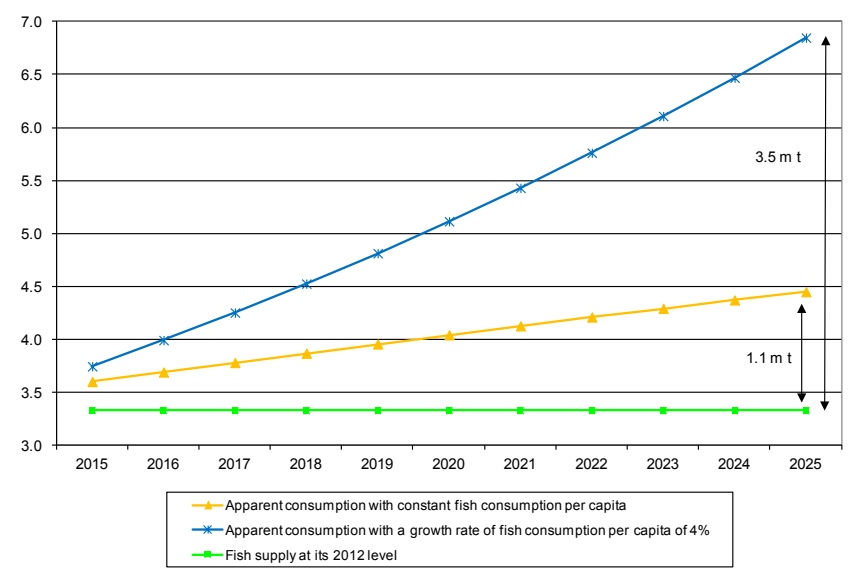

Figure 10: Scenario no.1. maintenance of the fish availability at its 2012 level for the period 2015-2025.

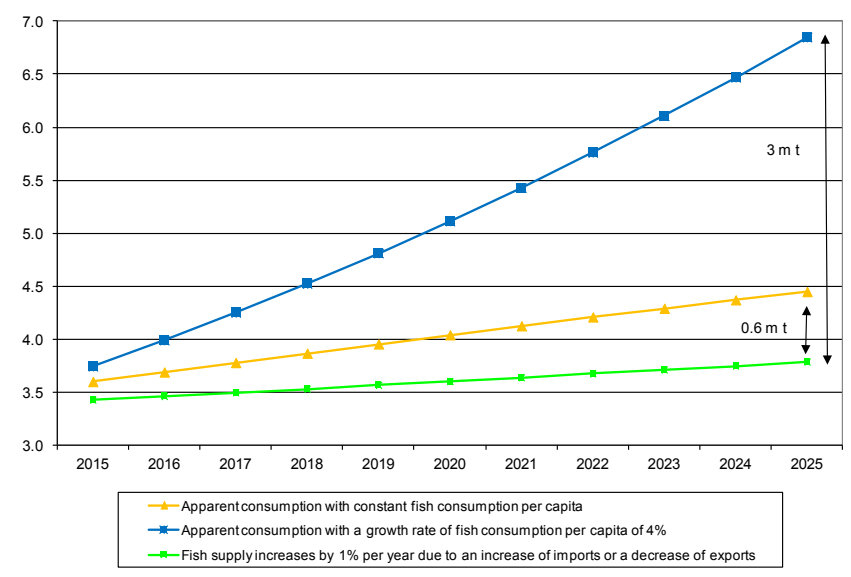

Figure 11: Scenario no. 2. increase of imports to satisfy the growing demand of fish consumption in cities of apparent consumption and fish supply.

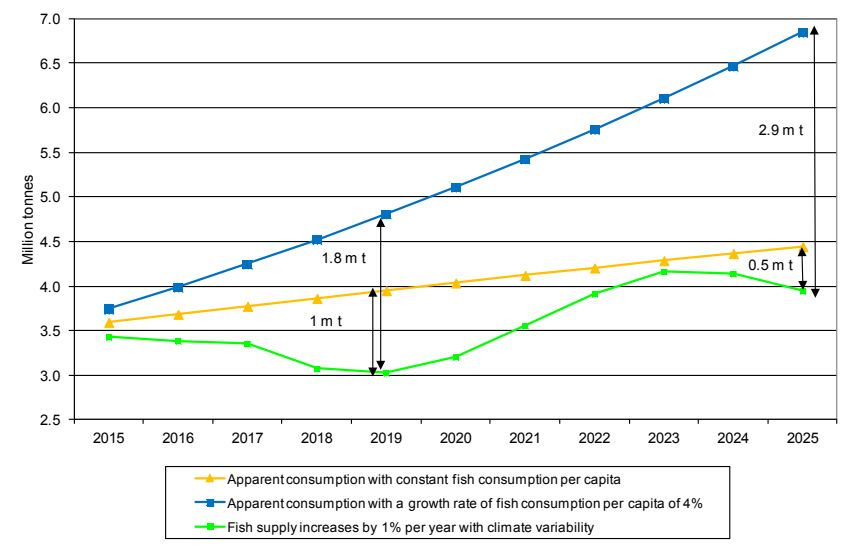

Figure 12: Optimistic scenario of fish availability and fish needs with climate variability (2015-2025).

fish consumption in cities. In this case, the gap will be slightly reduced, but not enough to satisfy the demand for fish of the whole population of West Africa. The boost of the purchasing power of middle class in cities will only generate an increase of imports, or a rerouting of exports towards national market of high or middle commercial values species. This may raise the net supply by $1 \%$ per year. As a result, the gap between the needs of the population and fish availability will be 0.6 million tonnes when considering only the growth of the population and 3 million tonnes when taking into account the increase of the consumption per capita.

For both scenarios, the increasing needs of the West African population will not be satisfied by a consequent increase in the level of fish supply. With a constant consumption per capita, the gap between demand and supply will range from 0.6 million tonnes at best situation to 1.1 million tonnes in the worst case. Taking into account the increasing consumption per capita, the gap raises from 3 to 3.5 million tonnes. Of course these figures are virtual, as the price mechanism will adjust the demand to the supply. In Senegal, sardinella prices fluctuate from 200 CFA francs ${ }^{12}$ per kilogram when landings are important up to 800 when they are rare [17]. This means that, in general, levels of fish price will increase by a certain factor, which is, however, difficult to estimate today. As a consequence of the price increase, poor people will, again, be pushed away from the fish market (exports of fish have started to affect the supply of national markets since the mid-eighties).

Scenarios with climate variability: Until now, projections of fish supply did not take into account the variability of resources due to the inter-annual variability and decadal cycles of the upwelling ${ }^{13}$. As decadal patterns for the CCLME has been observed by Roy and Cury [24] and presented below in this paper, it seems reasonable to apply the decadal cycles for the 2025 projections. That is all the more relevant, as the purpose of the presentation hereafter is not to give the amplitude of the abundance changes of sardinella population in West Africa, but to present the nutritional risk associated with a drastic diminution of sardinella in a particular year or during many years. For the purpose of the elaboration of the trend of sardinella catches, we can consider, from the observations of data collected by the Senegalese and the Mauritanian research centres since 1970, that three major periods with decrease and increase trends occurred: the first one from 1975 to 1989 , the second from 1990 to 1999 and the third one from 2000 to 2011. The year 2012 seems to have announced the return of the decreasing trend.

Extending these changes over the next decade, we can obtain annual sardinella catches that vary between 115.000 and 940.000 tonnes, with an average of 500.000 tonnes. This variation does not take into account catches of sardinellas (and their fluctuations), from Sierra Leone to Nigeria, conditioned by the Guinean Current and not the Canary Current. On this basis, we can elaborate two scenarios. The first scenario, called "optimistic scenario", is presented in Figure 12 while the pessimistic scenario is shown in Figure 13.

The optimistic scenario is based on the assumption that fish supply is not affected by any economic changes (imports, exports or production) but is under the influence of the climate variability. The 2012 starting point of catches is modified each year according to the positive or negative influence of the upwelling on the abundance during the spawning season and migrations. Climate variability has a multiannual influence that can't be restricted to the year of the catch ${ }^{14}$ due to the normal autocorrelation of climate across years as well as the life span of the fish (as it is for the cephalopods for instance). For instance, the peak of abundance in 1999 in Senegal had extended effect on the catches up to 2001 .

The optimistic scenario presents some good and bad surprises. On the good side, due to the positive effect of the upwelling, the fish ${ }_{12} 1000 \mathrm{CFA}=1.5 €$ or 1,9 \$US.

${ }^{13}$ Natural "climate variability" no human induced "climate change".

${ }^{14}$ The life cycle of sardinella is not fully understood. It is currently one the main research object of researchers in Morocco, Mauritania, Senegal and Gambia. 


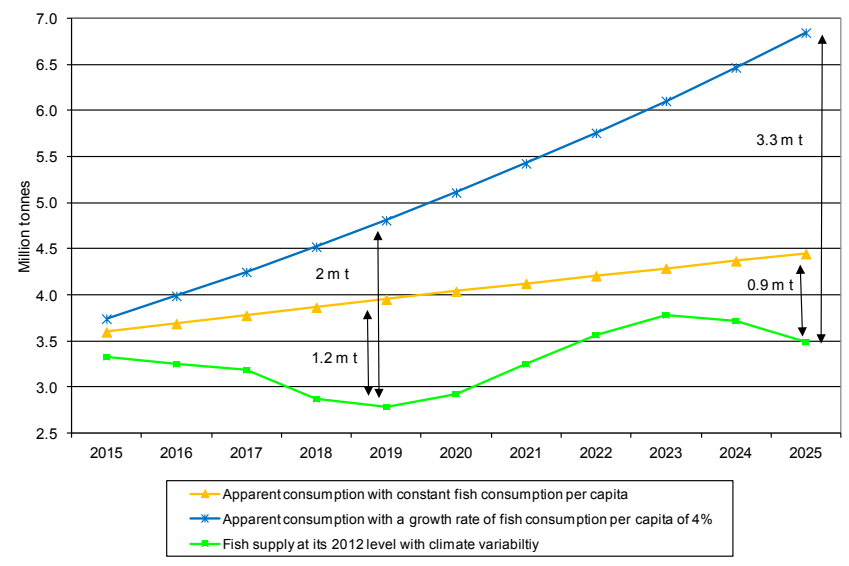

Figure 13: Pessimistic scenario of fish availability and fish needs with climate variability (2015-2025)

supply is nearly able to fulfil the demand (without raising of the fish consumption per capita). While under scenario 2 the gap between the demand and the fish supply was constantly increasing, in the optimistic scenario, the gap tends to narrow when the abundance of sardinellas has been boosted by good years of upwelling. In that way, the positive effect of upwelling contributes to a better supply of West African fish markets, assuming that the Asian demand doesn't change. Conversely, when the upwelling has an adverse effect on the sardinella abundance, climate variability plays against the fish supply of these markets. In scenario 2 , the gap of 0.6 million tonnes was reached only in 2025. Under this scenario, it can be attained earlier, e.g. in 2018 with a maximum gap of 1.1 million tonnes the year later.

The pessimistic scenario presented in Figure 13, based on the previous scenario 1 , gives, for the next decade, a more dramatic view than the optimistic scenario has provided for the fish supply in West African countries. The combined situation of the maintain of the 2012 supply and weak upwelling will enlarge the gap by 1.2 million tonnes already in 2018-2019 if we refer to a constant consumption per capita and by 2 million tonnes for a consumption that increases annually by $4 \%$. Conversely, the effect of strong upwelling improves the net supply but not enough to cover the demand. In other words, the occurrence of weak upwelling accentuates the downfall of fish supply while strong upwelling improves fish supply in West African countries but never at the level of satisfying the demand. The shortfall for both scenarios is between 0.1 and 0.5 million tonnes.

The presentation of these two scenarios shows clearly that the introduction of environmentally-driven variability of stocks involves a revision of the traditional and more static view of fish supply. It is important for policy-makers and fish traders to realize that fluctuations in catches (and supplies) are not only related to changes in fleet size or catching strategies but also to environmental parameter. The effects could be dramatic (as shown in Peru with the anchoveta collapse) and environmental parameters need to be integrated into the stock assessments and policy analyses.

The introduction of fluctuations in upwelling strength changes the way fish supply is analysed. It cannot be considered anymore as a parameter that evolves monotonically and environmental (inter-annual and decadal) variability has to be taken into account for the explanation of the past supply and forecast of its future. Through the fluctuations it generates, climate variability seems to be part of the price formation mechanism for small pelagics. The West African market, driven by the demand, is at the mercy of the supply, itself conditioned by the upwelling intensity. The supply variable is the only one that changes in the small pelagic market. The demand is more constant than supply, and remains at a higher level. Weak upwelling lead to low availability and high prices and strong upwelling lead to the opposite. While this assertion seems to be true for the industrial fishery that has its own market organisation, it has to be mitigated for the artisanal fishery as their processing and cold storage facilities are not able to absorb a high level of landings ${ }^{15}$ in periods of high abundance.

\section{Conclusion}

Small pelagics in West Africa are at the centre of food security stakes particularly in coastal areas. Though the net supply of fish in African countries was stable over the last decade, it is composed more and more exclusively of small pelagic species like sardinella which are highly dependent on upwelling conditions. In other words, the adequation of supply to demand is strongly affected by both the capacity to extract resources and the natural fluctuations of their productivity.

The development of the Asian market, still limited today to the European distant water fishery and its fish chain, constitutes a high nutritional risk for West African countries, as it will deflect sardinellas away from African routes. The risk for the African food fish supply is that this development opens new market opportunities for the artisanal fisheries (e.g. to export small pelagics) that could lead to a situation similar to that occurring with demersal fish, in which the artisanal fishery supplies the export market at the expense of the local ones.

Projections for the next decade indicate an increasing gap between estimated demand and supply under all scenarios. The more optimistic scenario shows that when environmental conditions are favourable, future fish supply cannot fulfil a growing population demand if per capita consumption remains at 2012 level. When environmental conditions are unfavourable, the supply-demand gap could rise to 1.8 million tonnes. However, even the best environmental conditions will not be able to satisfy the demand if the fish consumption per capita increases and the gap will progressively grow with time reaching 2.9 million tonnes in 2025. The pessimistic scenario presents a worrying picture of the future supply of West Africa where the gap between demand and supply may reach 3.3 million tonnes in 2025. In both scenarios, market mechanisms will adjust demand and supply by increasing the price of fish reducing therefore the accessibility for poor people and inhabitants of rural and areas far from the main fish markets. The foreseen deficiencies of fish supply will lead to nutritional loss, as some nutritional elements present in fish are not adequately represented in the foreseen substitutes (e.g. chicken). Therefore, climate variability increases the food security risks both in terms of quantity and quality.

Finally, the vagaries of the upwelling have never been taken into account for policy elaboration. This missing consideration has the consequence of managing fleets or fishing effort "forgetting" that stocks are variable. It seems also that governments forget that these stocks are shared and should be managed jointly. The integration of this environmental reality into fishery management would lead to an improved inter-annual adjustment of the fleet to the abundance of the stock. Regarding the food security policy, its integration will help to make better projections and to anticipate fish gluts and plan the necessary measures to ensure a better functioning of the sector and a decent fish supply in West Africa.

${ }^{15}$ Two recent examples: the first is in Nouakchott in 2001 (Mauritania). The number of fishing days was limited to three days per week in order to keep the price above a certain limit that insures the profitability of fishing unit of production; the second is in Saint Louis (Senegal) in March 2005, where prices dropped spectacularly since the beginning of the year and where canoes that land late during the day did not even find a buyer for their sardinella because of the impossibility of local facilities to absorb such a high level of catches. 
Citation: Failler P (2014) Climate Variability and Food Security in Africa: The Case of Small Pelagic Fish in West Africa. J Fisheries Livest Prod 2: 122. doi: $10.4172 / 2332-2608.1000122$

\section{References}

1. FAO (2013) The State of Food Insecurity in the World 20013, FAO, Rome.

2. WFC (2005) NEPAD, Technical Symposium and Fish for all summit, Abuja, Nigeria.

3. FAO (1995) International Conference on the Sustainable Contribution of Fisheries to Food Security. Kyoto, Japan, 4-9 December 1995. The Kyoto Declaration and Plan of Action, and summaries of technical papers presented, No serial publication, FAO, Rome.

4. FAO (2006) committee on fisheries sub-committee on fish trade, Tenth Session, Santiago de Compostela, Spain, 30 May - 02 June 2006, Fish Trade And Food Security.

5. Corberal E (2006) Climate Change in Africa: Linking Science and Policy for Adaptation, Workshop Report, The Royal Society, London, March 30th 2006, Tyndall Centre for Climate Change Research and School of Development Studies \& Overseas Development Group, University of East Anglia.

6. CCLME (2012) Canary current large marine ecosystem (CCLME) project: Project document, Dakar, Senegal.

7. Neiland, Béné eds (2003) Poverty and small-scale fisheries in West Africa, Klukwer Publisher.

8. Cunningham L (2005) Assessing the contribution of aquaculture to food security: a survey of methodologies. FAO Fisheries Circular. No. 1010, Rome.

9. Failler P, Dieng M (2001) The impact of European fishing agreements on fish market supply in Africa, DFID/CEMARE/CORDT report on fishing agreement, Dakar, Senegal.

10. FAO (2003) Report on the FAO group on the assessment of small pelagic fish off Northwest Africa, FAO Fisheries Report No. 723, Agadir, Morocco: FAO, Rome.

11. FAO (2004) Committee on Fisheries, Report of the ninth session of the SubCommittee on Fish Trade. Bremen, Germany.

12. Failler $P$ (2004) Trade policies and sustainability of fisheries sectors in West Africa, Proceedings of the workshop Conakry, Guinea. Fisheries, Trade and Environment in West Africa (PCEAO) Programme, ENDA / WWF / IUCN, Dakar.

13. Failler $P$ (2006) Impact of trade-linked policies on the management of fisheries in West Africa, 10 p., in Anonymous (2007), Proceedings of the Thirteenth Biennial Conference of the International Institute of Fisheries Economics \& Trade (IIFET), Portsmouth, UK: Rebuilding Fisheries in an Uncertain Environment. Compiled by Ann L. Shriver. International Institute of Fisheries Economics \& Trade, Corvallis, Oregon, USA

14. Benson T (2004) Africa's Food and Nutrition Security Situation; where Are We and How Did We Get Here? 2020 Discussion Paper 37 • August 2004 International Food Policy Research Institute, Washington, USA.

15. FAO (2005) The State of Food Insecurity in the World. Eradicating world hunger - key to achieving the Millennium Development Goals, FAO, Rome.

16. Failler, Sambe (2005) Present and future economic and nutritional consequences of the exploitation of small pelagic (sardinellas) in West Africa. Sustainable Livelihood Fisheries Program. FAO, Rome.

17. Deme M (2012) Study of migration of Senegalese fishermen in space CSRP Programme MIRAGE, IUCN, Dakar, Sénégal, $46 \mathrm{p}$.

18. Failler P (2003) Impacts of fishing agreements in Morocco, Mauritania, Senegal, Ghana and Seychelles. Dfid Policy Research Programme.

19. FAO (2014) Capture production ; commodities production and trade, FISTAT.

20. Anonymous (2004) Large Marine Ecosystem of the World; LME 27: Canary Current.

21. Binet D (1997) Climate and pelagics in the Canary and Guinea currents 1964 1993: the role of trade winds and the southern oscillation. Oceanologia Acta, 20: $177-190$

22. Fréon $P$ (1984) Des modèles de production appliqués a des fonctions de stock dépendantes des vents d'upwelling. Océanographie tropicale 19: 67-94.

23. Binet (2005) Notes sur la relation entre l'upwelling côtier et les stocks de sardinnelles, Personnal communication.

24. Roy C, Cury P (2003) Decadal environmental and ecological changes in the Canary Current Large Marine Ecosystem and adjacent waters: Patterns of connections and teleconnection.
25. Zeeberg J, Corten A Tjoe-Awie P Cocab J, Hamadyc B (2008) Climate modulates the effects of Sardinella aurita fisheries off Northwest Africa. Fishery Research 89: 65-75.

26. Zeeberg J (2003) Satellite imaging a valuable contribution to study of fishing stocks in Mauritania.

27. Braham CB, Fréon $P$, Laurec $A$, Demarcq $H$, Bez N (2014) New insights in the spatial dynamics of sardinella stocks off Mauritania (North-West Africa) based on logbook data analysis. Fisheries Research, 154: 195-204.

28. Roy C, Reason C (2001) ENSO related modulation of coastal upwelling in the eastern Atlantic. Progress in Oceanography, 49: 245-255.

29. FAO (2000) Country profile: Nigeria.

30. FAO (2008) Report of the FAO Working Group on the Assessment of Smal Pelagic Fish off Northwest Africa. Agadir, Morocco, 17-26 April 2007. FAO Fisheries Report/FAO Rapport sur les pêches. No. 849, Rome.

31. FAO (2014) The state of world fisheries and aquaculture, FAO, Rome.

32. Van den Brink (2004) Blue whiting exports to China a long time on the back burner this year, PFA News.

33. Chavance P, Ba M, Gascuel D, Pauly D (2004) Pêcheries maritimes écosystèmes et sociétés en Afrique de l'Ouest : Un demi-siècle de changement Actes du symposium international, Dakar, Sénégal, 24-28 Juin 2002. Bruxelles, Office des publications officielles des Communautés européennes.

34. Dahou K, Deme M (2002) Accords de pêche UE-Sénégal et commerce international: Respects des règlements internationaux, gestion durable des ressources et sécurité alimentaire, CRODT, Dakar, Senegal.

35. Failler $P$ (2006) Future prospects for fish and fishery products; 4. Fish consumption in the European Union in 2015 and 2030 - Part 1. Europe. FAO Fisheries Circular No. 972/4 Part 1, Rome.

36. FAO (2012) Fish and fishery products. World apparent consumption statistics based on Food Balance Sheets (1961-2009). FAO Rome.

37. Failler P (2009) Le poisson ouest-africain dans les mailles du commerce international, Effet de la libéralisation du commerce en Afrique de l'Ouest UNEP, Geneva.

38. Platt BS (1962) Tables of Representative values of foods commonly used in tropical countries. Spec Rep Ser Med Res Counc.

39. USDA (2009) Table of nutrients

40. FAO and US Department of Health, Education and Welfare (1968). Food Composition Table for use in Africa.

41. Mc Cance, Widdowson (1992) The Composition of Foods. The Royal Society of Chemistry, Cambridge.

42. CEDEAO-UE-UEMOA (2002) Afrique de l'Ouest - Communauté européenne ; Document de stratégie de coopération régionale et Programme indicatif régional pour la période 2003-2007.

43. Synge R, Failler P, Gascuel D (2008) Over-exploitation in West Africa's richest zones, African report.

44. Deme M, Diadhiou HD, Thiam D (2001) Effort de pêche, captures spécifiques et valeurs économiques des débarquements de la pêche continentale dans le fleuve Sénégal et au Sine Saloum. Projet Utilisation Durable des ressources Sauvages au Sénégal, CRODT/IUCN/ISRA, 56 p.

45. Neubacher H (1999) Seafood brain food of the future. Seafood Internationa 14: $24-25$

Citation: Failler P (2014) Climate Variability and Food Security in Africa: The Case of Small Pelagic Fish in West Africa. J Fisheries Livest Prod 2: 122. doi: 10.4172/2332-2608.1000122 